\title{
Migração Partidária na Câmara dos Deputados de 1987 a $2009 *$
}

\section{Andréa Freitas}

Doutoranda em Ciência Política pela Universidade de São Paulo (USP) e pesquisadora do Centro Brasileiro de Análise e Planejamento (Cebrap). E-mail: amfreitas1@gmail.com.

\section{INTRODUÇÃO}

\begin{abstract}
persistência do fenômeno da migração partidária no Brasil levou A a ciência política a afirmar que as trocas de legenda teriam um caráter endêmico, que fariam parte das práticas e costumes dos políticos brasileiros. Práticas que comprovariam a prevalência do comportamento individualista dos políticos, os quais, por meio da migração partidária, passaram a alterar a correlação de forças no interior do Parlamento sem o crivo eleitoral (Lamounier e Meneguello, 1986; Lima Junior, 1993; Mainwaring, 1991; Melo, 2004; Santos, 2001).

De fato, quase um terço dos deputados brasileiros troca de legenda pelo menos uma vez ao longo de uma legislatura. E mesmo a decisão do Tribunal Superior Eleitoral (TSE), confirmada pelo Supremo Tribunal Federal (STF), que coloca em risco o mandato dos migrantes, não foi capaz de impedir as trocas de legenda no momento anterior ao prazo de filiação mínimo com vistas às eleições de outubro de 2010. Desde
\end{abstract}

\footnotetext{
* Este artigo é parte da minha dissertação de mestrado, defendida em fevereiro de 2009. Agradeço muitíssimo ao meu orientador, Fernando Limongi, pela colaboração imensa no desenvolvimento do trabalho. Agradeço ainda à banca, professora Maria Hermínia Tavares de Almeida e professor Jairo Nicolau, cujos comentários foram extremamente valiosos. Por fim, agradeço à Fundação de Amparo à Pesquisa do Estado de São Paulo (Fapesp), que financiou a pesquisa.
}

DADOS - Revista de Ciências Sociais, Rio de Janeiro, vol. 55, n-4, 2012, pp. 951 a 986. 
março de 2007, quando o TSE determinou que o mandato pertence ao partido e não ao parlamentar, ocorreram 51 trocas de legenda.

No entanto, acredito que a migração partidária não é apenas o reflexo do comportamento individualista dos parlamentares. Assim sendo, este trabalho procura analisar o fenômeno das trocas de legenda no Brasil, com um enfoque diferente do que tradicionalmente se aplica. Em vez de explorar as ambições do migrante, procurei entender as trocas de legenda no agregado, buscando apreender como os atores coletivos - no caso, os partidos políticos - utilizam as trocas de legenda para aumentar seu poder na arena parlamentar e na arena eleitoral.

Não pretendo com isto afirmar que os parlamentares não busquem aumentar suas chances de sucesso quando mudam de partido. Ao contrário, eles só trocam de partido porque entendem que esta é uma estratégia vantajosa para suas carreiras políticas. Dito de outra forma: "Trocar de legendas passou a fazer parte do leque de ações desenvolvidas pelos membros do Congresso brasileiro com vistas à sobrevivência política" (Melo, 2004:64).

No entanto, uma troca de legenda é uma via de mão dupla, para que um parlamentar saia de um partido e entre em outro, no mínimo é necessário que o partido da entrada o aceite (Laver e Benoit, 2003; Desposato, 2006; Freitas, 2009). Mas esta não é a única opção. Em parlamentos o tamanho das bancadas é definidor da capacidade de ação dos partidos políticos, assim pode-se esperar que estes também desenvolvam estratégias para aumentar suas bancadas. Então, o objetivo deste texto é explorar o que os partidos ganham no momento em ocorre uma troca de legenda. O que se pretende é mostrar que os partidos políticos não são vítimas de parlamentares ultraindividualistas, aqueles atuam no processo e estimulam a migração partidária na busca por aumentar seus recursos. Aliciam parlamentares para aumentar seu acesso a cargos no Legislativo, para aumentar seu tempo no horário eleitoral gratuito e para angariar mais votos em regiões onde não eram bem votados.

Os estudos dedicados a explicar este fenômeno procuram entender as mudanças de legenda com foco na decisão individual do parlamentar, buscam entender, quais as vantagens que o indivíduo obtém neste ou naquele partido. Ou seja, focam suas análises "exclusivamente na racionalidade dos migrantes, ignorando os incentivos aos partidos a que os migrantes estão tentando se juntar" (Laver e Benoit, 2003:215, tra- 
dução da autora). E, acabam por concluir que o movimento migratório é "predominantemente governista" (Melo, 2004:164). Em outras palavras, deputados trocariam de partido almejando mais acesso a recursos de poder, ou seja, buscando partidos que compõem a base governista. Nas palavras de Desposato: "Para o Legislador, o acesso a recursos públicos é maximizado quando esse entra na coalizão de governo e vota com o Executivo" (2006:70, tradução da autora).

O fato é que não há bases objetivas para tal afirmação, como observaremos na primeira seção. Uma vez que as estratégias desenvolvidas pelos parlamentares se baseiam, em grande medida, em uma avaliação subjetiva. Políticos não controlam, ainda que procurem fazê-lo, as variáveis que influenciam as suas chances de reeleição, isto porque a passagem pelo crivo dos eleitores implica se submeter às incertezas próprias ao mercado eleitoral.

O ponto a frisar é: a avaliação do parlamentar é, em última análise, pessoal e esses cálculos dificilmente configurarão algo além de apostas. Sendo assim, é provável que, sob as mesmas condições objetivas, diferentes parlamentares farão diferentes apostas.

O acento na decisão e motivação individual do parlamentar faz com que os analistas desconsiderem o peso dos demais atores envolvidos nesse processo. Basicamente, parte-se do princípio de que os partidos políticos ${ }^{1}$ no Brasil são pouco importantes e que a migração partidária comprovaria esta afirmação.

Mas se no sistema político brasileiro os partidos políticos não importam, por que os parlamentares se dariam ao trabalho de trocar de partido? Dito de outra forma: não faz sentido trocar de partido se os mesmos não forem capazes de oferecer benefícios para os seus membros.

Assim, o objetivo deste trabalho é analisar as trocas de legenda ${ }^{2}$ na Câmara dos Deputados entre fevereiro de 1987 e outubro de 2009, da ótica dos partidos políticos. Parto da premissa de que parlamentares buscam maximizar suas chances de sucesso na carreira política; no entanto, entendo que os benefícios perseguidos por estes atores são obtidos apenas por meio dos partidos. Entendo, ainda, que ao nos concentrarmos apenas na motivação individual dos parlamentares, perdermos a complexidade da dimensão estratégica envolvida na situação.

Esta afirmação se baseia na constatação de que as trocas de legenda no Brasil são concentradas em momentos específicos no tempo, como ve- 
remos na segunda seção. Parlamentares com diferentes características e ambições trocam de partido em um mesmo período. Muitas vezes em apenas um ou dois dias são definidas 50\% das trocas de legenda de uma legislatura. Ainda, esta concentração se dá em períodos decisivos para os partidos políticos ${ }^{3}$. Isto porque, nestes meses se define a distribuição de poder entre os partidos no parlamento, bem como quanto tempo será dado aos partidos no horário gratuito de propaganda eleitoral (HGPE), como veremos na terceira e quarta seções.

Devemos considerar, ainda, que, para os partidos, cada membro conta na arena parlamentar, particularmente em um sistema político que apresenta altos índices de disciplina. Na arena eleitoral, por sua vez, cada novo membro que o partido recebe traz com ele os votos dos eleitores que permanecerem fiéis a esse parlamentar. Esses incentivos são diretos e são dados aos partidos. Para os parlamentares, os benefícios são indiretos e apropriáveis apenas através dos partidos.

\section{UM MOVIMENTO EM DIREÇÃO AO GOVERNO?}

A literatura explica a migração partidária a partir da premissa de que os parlamentares buscam maximizar suas chances de sucesso na carreira política, ou seja, buscam se reeleger. Sendo assim, ao trocar de legenda, os parlamentares dariam preferência a partidos que possam lhe fornecer melhores recursos na luta por sobrevivência política. Estes recursos são, basicamente, controlados pelo Executivo (tais como cargos e emendas ao orçamento), o que tornaria a coalizão governista potencialmente atrativa.

Potencialmente atrativa, porque, segundo Melo, o poder de atração da coalizão varia ao longo do tempo em função de dois fatores, a saber: a popularidade do presidente e a distribuição de poder dentro da coalizão. Sendo assim, o potencial de atração da coalizão do governo aumenta quando os "partidos governistas, [estão] inseridos em ministérios de coalizão comandados por presidentes bem avaliados pela população" (2004:164); e esse potencial é ainda maior "quanto mais central a posição da legenda [no governo]" (ibidem:165).

Desposato (2006) simplifica esse argumento afirmando que rumar para a coalizão governista e votar de maneira disciplinada as propostas do Executivo maximiza o acesso dos parlamentares a recursos preciosos na arena eleitoral. Ou seja, parlamentares aumentam suas chances de sucesso ao entrarem na coalizão governista. 
Temos que as trocas teriam por objetivo final obter maior apoio eleitoral. E como os meios para transferir recursos públicos para as bases eleitorais estão concentrados nas mãos do Executivo, deputados trocariam de partido tomando a direção do governo justamente para obter acesso privilegiado a estes recursos, ou sinalização positiva para o eleitorado, quando a inserção se dá em partidos da coalizão capitaneados por presidentes bem avaliados (Melo, 2004; Desposato, 2006).

Na Tabela 1 observamos a porcentagem de trocas de legenda segundo a posição do partido do parlamentar em relação ao governo, que foi dividida em três, a saber: partidos da coalizão, partidos satélites ${ }^{4}$ e partidos de oposição.

A separação dos partidos em três categorias, em vez de apenas em duas, oposição e governo, é importante, pois não podemos considerar partidos em que 90\%, 95\%, da bancada votam de maneira sistemática com o governo como partidos da oposição ${ }^{5}$ Vejamos, a questão não é propriamente se estes partidos a poiam ou não o Executivo, certamente isso não é suficiente para declaramos que esses partidos são diferentes dos demais partidos da oposição, o ponto é entender se esses partidos têm ou não acesso a recursos que os partidos de oposição não possuem.

Se os parlamentares trocam de partido buscando acessar recursos que são controlados pelo Executivo e, se os partidos satélites apoiam o Executivo e com isso acessam recursos controlados por este poder de maneira diferenciada dos partidos que não apoiam o Executivo, então temos que encará-los como diferentes. Este é precisamente o caso. Em trabalho anterior (Freitas e Mesquita, 2008), verificamos que os partidos satélites têm taxas de execução orçamentária similar, por vezes pouco superior à taxa de execução dos partidos que compõem formalmente a coalizão, ao mesmo tempo em que possuem taxas muito superiores às dos partidos que não apoiam o Executivo, ou seja, os partidos da oposição. Neste caso, têm acesso a recursos que os partidos da oposição não têm. Por outro lado, não gozam completamente dos recursos que gozam os partidos do governo, uma vez que não possuem pastas ministeriais.

Assim, a cada troca de legenda classifico o partido inicial do parlamentar e o partido de destino em relação ao governo na data em que a troca foi realizada. Neste sentido, a unidade de análise é a mudança de partido, e não o migrante. Ou seja, se um parlamentar troca de partido mais de uma vez, cada troca é considerada. 
Tabela 1

Trocas de Legenda: Origem e Destino a partir da Posição do Partido em relação ao Governo (1987 a 2009)*

\begin{tabular}{l|c|c|c|c|c}
\hline $\begin{array}{c}\text { Destino } \\
\text { Origem }\end{array}$ & $\begin{array}{c}\text { Coalizão } \\
* *\end{array}$ & Satélite*** & Oposição**** & $\begin{array}{c}\text { Sem } \\
\text { Partido**** }^{* * *}\end{array}$ & Total \\
\hline Coalizão & 16,3 & 8,7 & 24,2 & 1,1 & $50,4(709)$ \\
Satélite & 8,0 & 3,2 & 2,2 & 0,4 & $13,8(194)$ \\
Oposição & 14,3 & 4,8 & 14,0 & 1,4 & $34,5(485)$ \\
Sem Partido & 0,9 & 0,0 & 0,5 & 0,0 & $1,4(19)$ \\
\hline Total & $39,4(554)$ & $16,7(235)$ & $40,9(576)$ & $3,0(42)$ & $100,0(1.407)$ \\
\hline
\end{tabular}

Fonte: Banco de Dados Legislativos, Cebrap.

${ }^{*}$ Foram consideradas todas as trocas de partido que ocorreram entre 1 을 $/ 1987$ e 31/10/2009, assim os parlamentares que trocaram de partido mais que uma vez têm todas as trocas incluídas. Ainda não foram consideradas trocas de legendas aquelas que ocorreram por meio de fusão, tal qual a do PL com o PRONA que formou o PR.

** Coalizão definida por Figueiredo, 2007.

*** Satélites são os partidos que apoiam sistematicamente o Executivo, ainda que não façam parte formalmente da coalizão presidencial, ou seja, não possuam ministérios. Para mais ver Limongi e Freitas, 2005 ou Freitas, 2009.

**** Oposição são todos os demais partidos.

***** Só entraram na categoria sem partido aqueles parlamentares que ficaram mais do que seis meses sem nenhuma filiação partidária, os demais que em geral ficam em média 10 dias sem partido, tiveram sua passagem por sem partido desconsiderada, passando do partido inicial para o final.

A porcentagem de migrações que têm como destino os partidos que estão na coalizão ou que estão na oposição é bastante parecida, representando, respectivamente, $39,4 \%$ e $40,9 \%$. Não podemos falar o mesmo da saída dos partidos segundo sua posição em relação ao governo. A coalizão governista perde $50,4 \%$ de seus parlamentares, enquanto os partidos da oposição perdem $34,5 \%$.

De fato, o movimento migratório se revela eminentemente governista, mas não no sentido que usualmente se apregoa: verdadeiramente, são os parlamentares filiados a partidos da coalizão aqueles que mais trocam de legenda. Curiosamente, $24 \%$ deles saem da coalizão governista e rumam para a oposição, contra $16 \%$ que saem da coalizão em direção a partidos que também fazem parte da coalizão, ou seja, trocam entre partidos com igual acesso a recursos controlados pelo Executivo.

Pode-se argumentar que este equilíbrio no destino dos parlamentares seria fruto da análise agregada dos dados, que envolvem as legislaturas de 1987 e 1991, cujos presidentes não foram tão bem-sucedidos. Ou seja, se, como afirma Melo, o potencial de atração da coalizão governista é afetado por presidentes mal avaliados, seria de se esperar que a co- 
alizão perdesse parlamentares nas legislaturas de 1987 e 1991, uma vez que Sarney e Collor tiveram governos mal avaliados pela população.

No entanto, isso não se verifica na observação desagregada das legislaturas $^{6}$. Olhando para as legislaturas que se iniciam em 1995, 1999, 2003 e 2007, cujos presidentes foram bem avaliados, temos: na legislatura de 1995, apenas 8,2\% das trocas de legenda têm como origem a oposição e destino a coalizão; na legislatura de 1999, este movimento representa apenas $17 \%$ das trocas, em 2003, 23\%, e, em 2007, $22 \%$.

Ainda, as trocas de legenda entre partidos da coalizão, ou seja, com origem e destino na coalizão governista, representam 25\% em 1995, 31\% em 1999, 21\% em 2003 e 5\% em 2007. Em 1999, a proporção de saída de parlamentares da coalizão é quase a mesma da entrada, $28 \%$ e $31 \%$, respectivamente. Em 2007, o movimento se concentra em direção aos partidos satélites: cerca de $55 \%$ dos parlamentares rumam para partidos nesta posição.

Mesmo nas legislaturas de 2003 e 2007 - nas quais o movimento em direção à coalizão aumenta - as trocas de legenda entre partidos de fora da coalizão, ou seja, os de oposição ou satélites, para o governo, são da ordem de $32 \%$ e $25 \%$, respectivamente.

Poderíamos argumentar, ainda, que certos partidos da coalizão governista seriam mais interessantes que outros, ou seja, que o acesso a recursos do aparato governamental seria diferente entre os partidos que formam a coalizão. De fato, imaginar que o partido do presidente tem mais acesso a recursos do que partidos que têm apenas um ministério faz bastante sentido.

No entanto, 20 das 101 saídas da coalizão do governo na legislatura de 1995 têm origem no Partido da Social Democracia Brasileira (PSDB), partido do então presidente Fernando Henrique Cardoso, e outras 26 têm como origem o Partido da Frente Liberal (PFL), do vice-presidente, Marco Maciel, que durante o governo FHC teve entre cinco e três ministérios (o PSDB, no mesmo, período variou entre seis e três ministérios). Em 1999, 86 trocas de legenda têm como origem o PSDB ou o PFL, cada um dos partidos perde exatos 43 membros. Em 2003, o Partido dos Trabalhadores (PT), o partido do então presidente Luiz Inácio Lula da Silva, perde 12 membros, e o Partido Liberal (PL), do vice-presidente, José Alencar, perde 27 membros. O PL deteve controle sobre apenas 
dois ministérios, mas o governo Lula distribuiu os ministérios de maneira bastante desigual, concentrando as pastas nas mãos do PT.

Mas para onde vão os membros que saem destes partidos? Em 1995, o então Partido Progressista Brasileiro (PPB), atual Partido Progressista (PP), é quem mais atrai os parlamentares do PSDB e do PFL. Dos 46 parlamentares que saem destes partidos, 19 rumam para o PPB, outros sete parlamentares seguem para o Partido do Movimento Democrático Brasileiro (PMDB), os demais vão para PL, Partido Trabalhista Brasileiro (PTB) e até para partidos da oposição, como o Partido Popular Socialista (PPS) e o Partido da Mobilização Nacional (PMN). Ocorre ainda um movimento curioso: cinco parlamentares saem do PSDB e vão para o PFL, e outros três fazem o movimento inverso, deixando o PFL rumo ao PSDB.

Em 1999, dos 83 parlamentares que saem do PSDB e do PFL, 15 vão para o PMDB, seguidos de perto por PPB, PTB e PL, que recebem, respectivamente, 12, 12 e 11 novos membros. O movimento curioso que ocorre em 1995 se repete nesta legislatura: seis parlamentares saem do PSDB e vão para o PFL e oito saem do PFL e vão para o PSDB.

Em 2003, os parlamentares que saem do PT fundam o Partido Socialismo e Liberdade (PSOL), com exceção de dois, que vão um para o Partido Democrático Trabalhista (PDT) e outro para o PMDB. Entre os que saem do PL, seis vão para o PTB, cinco para o Partido Socialista Brasileiro (PSB), os outros se dividem entre PDT, PP e Partido Social Liberal (PSL). Curiosamente, outros quatro parlamentares saem do PL e vão para o PSDB e o PFL, partidos que encabeçam a oposição ao governo Lula.

PL e PTB são os partidos da coalizão do governo Lula que mais receberam novos membros durante seus governos, respectivamente 43 e 48, em 2003, e 16 e 1, em 2007. Durante as legislaturas de 1995 e 1999, PL e PTB recebem um total de 66 novos membros, 35 e 31, respectivamente.

De todo o observado, não há como explicar as trocas de legenda pela afirmação que os parlamentares rumam à coalizão do governo em busca de converter seu apoio ao Executivo em recursos, e estes em voto. Poderíamos, no entanto, afirmar que parte das trocas tem, sim, este objetivo, mas ainda assim estaríamos explicando muito pouco do movimento entre as legendas. 
Verifica-se, por outro lado, uma intensa movimentação no interior da coalizão do governo. Ou seja, um intenso "entra e sai" nos partidos que possuem igual acesso aos benefícios fornecidos pela proximidade com o Executivo. Mas o que levava um parlamentar a abandonar o PSDB e entrar no PFL durante o governo Fernando Henrique? Ou fazer o movimento inverso? Por que os parlamentares migram, saindo e entrando em partidos que se comportam de maneira semelhante e que têm igual acesso aos recursos distribuídos pelo Executivo? Ou, porque 33\% do total de parlamentares que sai da coalizão deixa o partido do presidente?

Os modelos desenvolvidos para entender as trocas de legenda no Brasil partem do ponto de vista do migrante. A ideia é simples: entender as motivações individuais dos parlamentares a cada troca de legenda por meio de proxies que procuram medir os benefícios que os partidos podem trazer para os deputados. No entanto, estas análises não dão conta da explicação do fenômeno, apenas parte das trocas, e parte muito pequena do montante total.

Trocar ou não de legenda é uma decisão que envolve um número de variáveis considerável. Partimos do princípio que, ao trocar de partido, os parlamentares estão buscando melhorar as possibilidades de sucesso em sua carreira política; sendo assim, buscam partidos que possam, em última análise, fornecer mais benefícios do que os partidos em que eles se encontram.

No entanto, os parlamentares não buscam os mesmos benefícios, pois, se assim fosse, as trocas de legenda seriam concentradas em um partido ou em um grupo de partidos com as mesmas características, tornando bastante simples identificar as motivações que levam os deputados a trocar de legenda. É esta simplificação que leva, por exemplo, à ideia de que parlamentares trocam de partido no sentido da coalizão governista, onde se concentram os recursos, que teoricamente são os mais cobiçados pelos políticos.

Há muito mais a considerar. Não há porque imaginarmos, apenas pelo fato de que todos são parlamentares, que todos têm o mesmo objetivo. Enquanto alguns trocaram de partido pensando na arena parlamentar, outros o fazem pensando na arena eleitoral; outros, por sua vez, se preocupam com a correlação de forças em seus estados. Neste jogo multidimensional existem arenas ocultas, ou jogos ocultos, plagiando Tsebelis (1998), os quais não conseguimos perceber. 
Devemos, pois, considerar que parlamentares têm objetivos diversos e desenvolvem estratégias diferentes para alcançar estes objetivos. Se alguns deputados trocam de partido para aumentar sua influência no Congresso, visando ampliar as chances de aprovação de uma determinada política, outros podem buscar cargos que aumentem sua visibilidade junto ao eleitor. Outros, ainda, podem desejar se aproximar do governo estadual ou de lideranças em seu estado ou município. Outros, por sua vez, podem almejar alçar voos mais altos, tendo em vista o Executivo nacional. Outros podem simplesmente buscar partidos mais próximos de suas convicções ideológicas.

Em poucas palavras, mesmo em termos de carreira, os parlamentares podem possuir objetivos bastante diferentes. E, certamente, as estratégias que estes parlamentares desenvolvem para alcançar seus objetivos são também bastante diferentes.

E por mais que todos pretendessem as mesmas coisas e desenvolvessem estratégias parecidas para obter o que desejam, ainda assim eles podem simplesmente não alcançar o objetivo almejado. Ou seja, mensurar os objetivos dos parlamentares ao trocarem de legenda não é simples. Heller e Mershon, depois de estudar o fenômeno da migração partidária na Espanha e na Itália, afirmam (2004: 3): “Ambição é impossível de medir e difícil de identificar. É improvável que políticos admitam ter qualquer ambição que não servir aos eleitores e a seus partidos, por exemplo. A tentação de pressupor o desejo dos políticos promoverem suas carreiras e encontrar evidência desse desejo é grande, no entanto, é equivocada".

Se quisermos explicar a migração partidária não podemos manter o foco apenas no migrante. A pergunta não pode ser o que este busca individualmente, mas, sim, o que a migração partidária revela sobre o sistema político, sobre o comportamento dos partidos e sobre as estratégias à disposição dos atores que agem neste sistema. Na próxima seção apresento uma hipótese alternativa para entendermos o porquê da migração partidária.

\section{MIGRAÇÃO PARTIDÁRIA: CONCENTRAÇÃO NO TEMPO}

O fenômeno da migração partidária, a meu ver, deve ser entendido a partir da consideração de dois momentos distintos no tempo. O primeiro, que vai do fim do bipartidarismo até a eleição de FHC, no qual aspectos conjunturais explicariam a migração. Mais precisamente, a 
reconfiguração e adaptação ao regime democrático e multipartidário. E o segundo, entre 1995 até o período atual, no qual aspectos conjunturais ligados à transição democrática não estão mais presentes, o que torna explicar as trocas de legenda mais desafiador e possibilita a referência a novos elementos para uma explicação mais completa do funcionamento do sistema político brasileiro.

É possível verificar claramente que o movimento das bancadas assume características diferentes a partir da legislatura que se inicia em 1995, basicamente:

1. Inversão do sentido: as trocas de legenda deixam de ser na direção dos novos e pequenos partidos, passando a ocorrer na direção dos grandes partidos, implicando inclusive uma redução da fragmentação partidária na Câmara (Nicolau, 1996; Araújo, 2000).

2. A distribuição no tempo: as trocas de legenda entre 1987 e 1994 são dispersas no tempo e influenciadas pelo fracasso dos planos econômicos, criação de novos partidos, impeachment do presidente, entre outros fatores conjunturais. E a partir da legislatura 1995, estas passam a

Gráfico 1

Porcentagem de Migrantes por Período

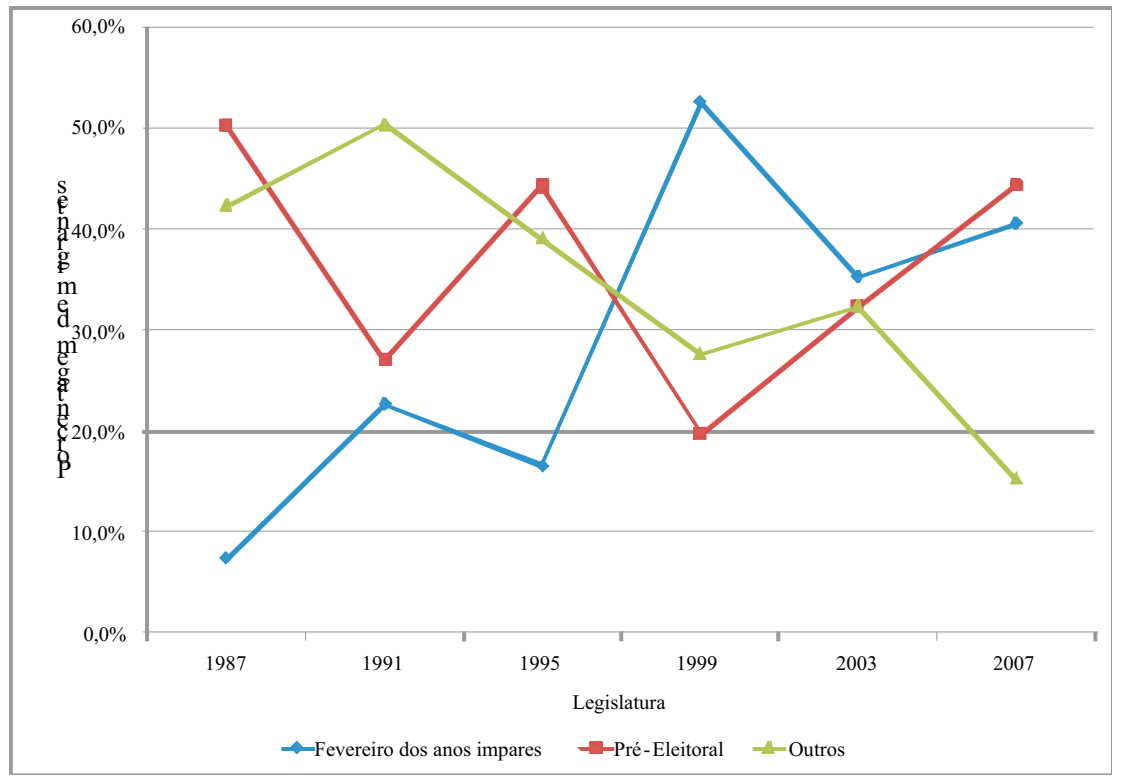

Fonte: Banco de Dados Legislativos, Cebrap. 
apresentar uma clara concentração em determinados períodos das legislaturas (Melo, 2004; Diniz, 2000; Araújo, 2000).

Vejamos, no Gráfico 1 que nas legislaturas de 1987 e de 1991 as trocas de legenda são dispersas ao longo de toda a legislatura, conforme apontado pela linha outros períodos e nos períodos pré-eleitorais ${ }^{7}$, ou seja, próximas ao fim do período de filiação mínimo com vista às eleições subsequentes. Este período coincide com a data de definição das bancadas com vistas à distribuição no tempo do horário eleitoral.

A partir de 1995, começa a se desenhar um quadro diferente. As trocas de legenda passam a se concentrar nos fevereiros dos anos impares, principalmente de 1999 em diante, e há uma redução significativa das trocas de legenda em outros períodos, que já se desenha fortemente em 1995. A questão é: por que parlamentares com objetivos diferentes, de partidos diferentes, trocam de legenda em um mesmo momento no tempo? Penso que entender o que acontece nos períodos em que as trocas de legenda se concentram é fundamental para entendermos o porquê dessas trocas.

Na próxima seção, faço uma análise das trocas de legenda associadas a períodos pré-eleitorais. Diniz (2000) é quem primeiro a ponta para uma profunda associação entre trocas de legenda e os prazos determinados no calendário eleitoral. A questão agora é explorar esta relação, procurando evidenciar o que está em jogo nestes momentos.

\section{REFLEXOS DA COMPETIÇÃO NA ARENA ELEITORAL}

Desde a promulgação da Constituinte, a cada nova eleição foi estabelecida uma nova regra eleitoral. Entre as diversas modificações que ocorreram, duas delas afetaram diretamente as migrações partidárias no interior da Câmara dos Deputados, a saber: a mudança no tempo de filiação mínima com vistas à eleição, e a distribuição do tempo do horário eleitoral gratuito.

A regulamentação dos dois temas foi objeto de intensa disputa política no interior das Casas legislativas ${ }^{8}$, o que mostra que os partidos políticos perceberam a importância das duas questões para alcançar seus objetivos. Vejamos, então, quais foram as modificações na lei eleitoral e suas implicações na migração partidária.

A eleição presidencial de outubro de 1989 foi regulada pela Lei no 7.773, de junho de 1988. Seu art. 17 determina que a distribuição do ho- 
rário eleitoral gratuito seja realizada em função do tamanho das bancadas dos partidos políticos no Congresso Nacional - Senado Federal e Câmara dos Deputados - e a data a ser considerada para este fim é o término do prazo de registro das candidaturas, ou seja, 17 de agosto de 1989. O tempo de propaganda no horário eleitoral gratuito seria distribuído da seguinte forma: partidos políticos sem representação no Congresso Nacional, 30 segundos; com até 20 congressistas, 5 minutos; de 21 a 60 congressistas, 10 minutos; de 61 a 120 congressistas, 13 minutos; de 121 a 200 congressistas, 16 minutos; acima de 200 congressistas, 22 minutos.

O Gráfico 2 apresenta as trocas de legenda ocorridas ao longo do ano de 1989. Podemos observar que há um pico de mudanças que se inicia em junho, com a aprovação da Lei no 7.773, e se encerra exatamente no dia 17 de agosto de 1989, no fim do prazo de contabilização das bancadas partidárias com vistas à distribuição do horário eleitoral gratuito. Somente entre a data da aprovação da lei e o fim do prazo ocorrem 65 trocas de legenda.

A Tabela 2 mostra a bancada dos principais partidos na Câmara dos Deputados no primeiro dia da legislatura e no fim do prazo de contabi-

Gráfico 2

Número de Trocas de Legenda no Ano de 1989

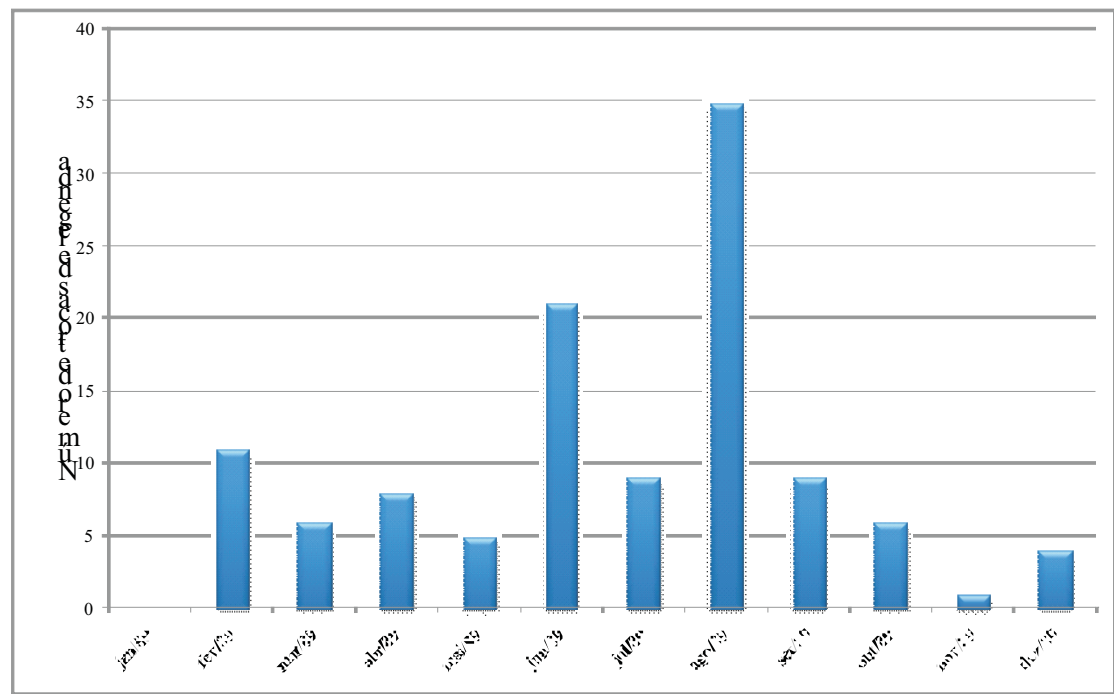

Fonte: Banco de Dados Legislativos, Cebrap. 
lização das bancadas. Ficam na linha divisória entre as faixas determinadas pela lei, PDC, PL, PRN, PSDB, PTB e PMDB. Não há de ser uma coincidência o fato de as trocas de legenda se concentrarem, justamente, nestes partidos.

Tabela 2

Composição das Principais Bancadas Partidárias em 1/2/1987 e 18/8/1989

\begin{tabular}{|c|c|c|c|c|c|c|c|c|c|c|c|c|}
\hline Data & $\begin{array}{l}\text { Casa Le- } \\
\text { gislativa }\end{array}$ & PDC & PDS & PDT & PFL & PL & PMDB & PRN & PSB & PSDB & PTB & PT \\
\hline \multirow{3}{*}{$1 / 2 / 1987$} & $\begin{array}{l}\text { Câmara } \\
\text { dos Depu- } \\
\text { tados }\end{array}$ & 5 & 33 & 24 & 118 & 6 & 259 & 0 & 1 & 0 & 17 & 16 \\
\hline & $\begin{array}{l}\text { Senado Fe- } \\
\text { deral }\end{array}$ & 1 & 5 & 2 & 14 & 1 & 45 & 0 & 1 & 0 & 1 & 0 \\
\hline & Total & 6 & 38 & 26 & 132 & 7 & 304 & 0 & 2 & 0 & 18 & 16 \\
\hline \multirow{3}{*}{$18 / 8 / 1989$} & $\begin{array}{l}\text { Câmara } \\
\text { dos Depu- } \\
\text { tados }\end{array}$ & 16 & 29 & 29 & 89 & 22 & 175 & 21 & 6 & 51 & 19 & 16 \\
\hline & $\begin{array}{l}\text { Senado Fe- } \\
\text { deral }\end{array}$ & 4 & 2 & 3 & 12 & 1 & 31 & 1 & 2 & 10 & 4 & 0 \\
\hline & Total & 20 & 31 & 32 & 101 & 23 & 206 & 22 & 8 & 61 & 23 & 16 \\
\hline
\end{tabular}

Fonte: Banco de Dados Legislativos, Cebrap

No Gráfico $3^{9}$, podemos observar os partidos que estão na linha divisória entre as faixas de distribuição do horário eleitoral gratuito. À exceção do PDC e do PTB, todos os partidos deste grupo aumentam suas bancadas, conseguindo exatamente o número necessário de parlamentares para mudar de faixa dias antes da data limite.

O PL dá o maior salto, passa de sete deputados para 22, três dias antes do fim do prazo; o PRN e o PSDB crescem ao longo dos meses, dando um leve salto nos dias anteriores ao fim do prazo. O PFL e o PMDB são os partidos que mais perdem deputados neste período, 10 e 27 deputados, respectivamente.

Ainda assim, o PMDB consegue se manter na faixa que garante o tempo máximo de TV. O PFL, por sua vez, é o único partido que tem seu tempo diminuído quando comparamos a bancada eleita e a bancada na data limite.

As eleições proporcionais de 1990 foram regidas por resoluções do Tribunal Superior Eleitoral (TSE). A Resolução 16.347 determina que os 
Gráfico 3

Bancada dos Partidos na Data Limite

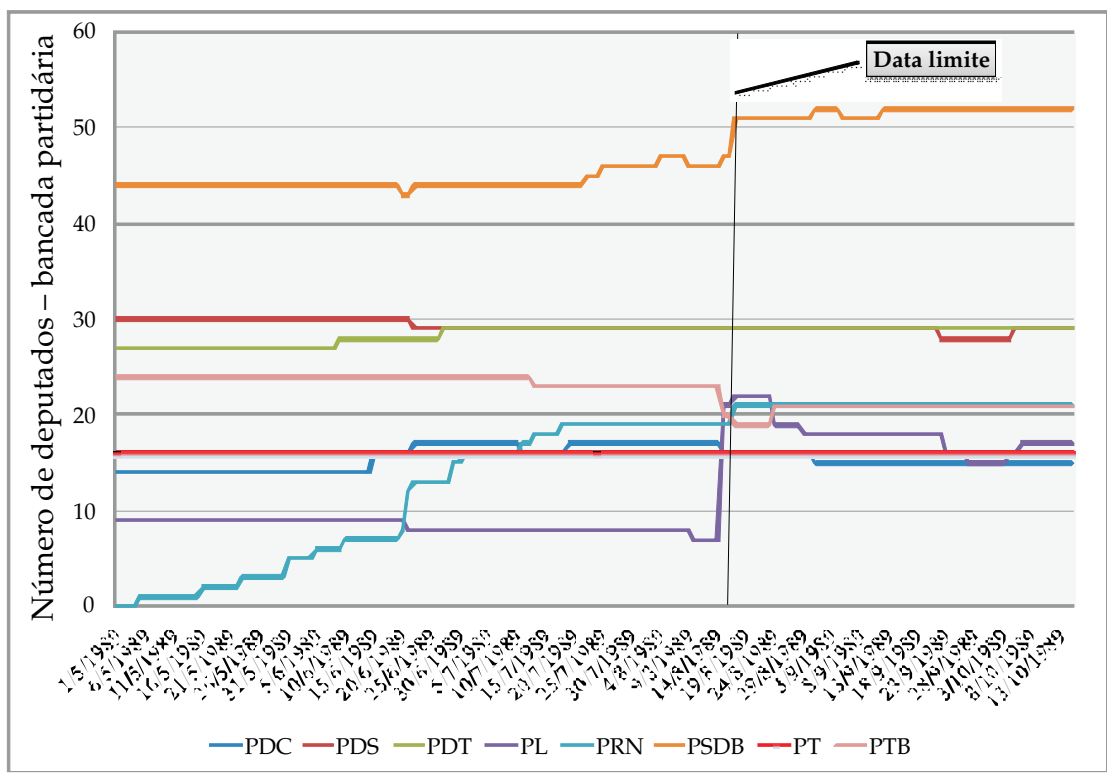

Fonte: Banco de Dados Legislativos, Cebrap.

candidatos deveriam estar filiados aos seus partidos em 3 de abril de 1990.

No Gráfico 4, observamos que o movimento migratório se acentua com a aproximação do fim do prazo. A resolução do TSE que regulamenta a distribuição do HPGE não causa novas trocas, pois a data determinada para a contabilização das bancadas partidárias é a mesma do fim do prazo de filiação mínima (3/4/1990) e a publicação da Resolução ocorre em 17 de abril, ou seja, quando o prazo já havia se encerrado. Sendo assim, a lei eleitoral nas eleições de 1990 não incentiva as trocas, mas limita o tempo em que elas podem ocorrer, influindo nas estratégias disponíveis para os atores políticos.

Grande parte da literatura, nacional e internacional, aponta que uma das principais causas para a migração partidária é o reposicionamento dos deputados com vistas a obter vantagens na arena eleitoral. Mas as trocas de legenda que ocorrem em 1989, ainda que claramente relacionadas à arena eleitoral, não são relacionadas a interesses imediatos dos parlamentares. O que estava em jogo era uma eleição presidencial em que a maioria dos parlamentares não concorria. O interesse eleitoral é, 
Gráfico 4

Número de Trocas de Legenda no Ano de 1990

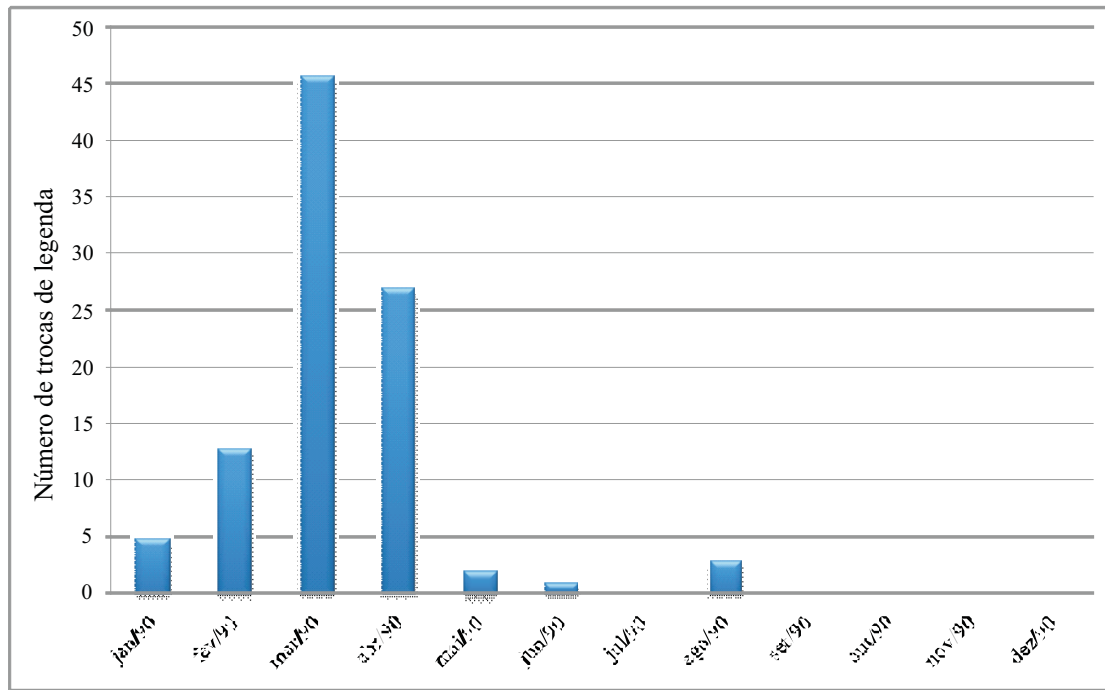

Fonte: Banco de Dados Legislativos, Cebrap.

no máximo, indireto, já que mediado pelos candidatos presidenciais dos partidos aos quais os parlamentares são filiados.

Dito de maneira inversa: quase todos os partidos políticos com representação na Câmara dos Deputados apresentam candidato à presidência. Esses, sim, possuem um enorme incentivo para atrair membros - o aumento do tempo de exposição no horário eleitoral gratuito. A Tabela 2 e o Gráfico 3 mostram, de forma clara, que os partidos buscaram aumentar seu tempo no horário eleitoral e encerram a busca por novos membros quando mudam de faixa de distribuição do HPGE.

Nas eleições 1989 são os partidos políticos e as candidaturas presidenciais que promovem as trocas de legendas para, com isso, manter ou conquistar tempo no HPGE através do aumento de suas bancadas.

Nas migrações anteriores a eleição de 1990, no entanto, o estímulo "tempo de horário eleitoral" não está presente de forma tão direta. Aqui, pesa de forma direta a restrição - tempo de filiação mínimo - à candidatura, mesmo que se pudesse antecipar que a distribuição de tempo na TV fosse seguir algum critério em que o tamanho das bancadas fosse levado em conta. Ainda assim, as faixas para a distribuição de tempo não eram conhecidas e não podiam influenciar na decisão de trocar de legenda. Estas trocas podem ser caracterizadas como diferen- 
Gráfico 5

Número de Trocas de Legenda Ocorridas entre Abril de 1993 e Maio de 1994

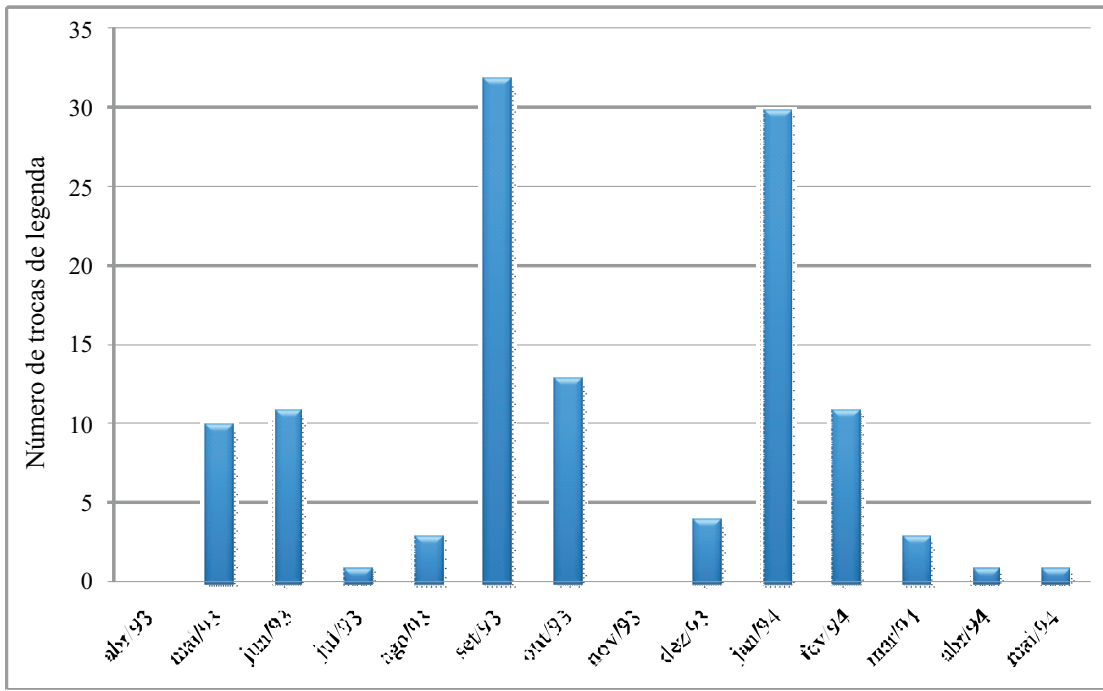

Fonte: Banco de Dados Legislativos, Cebrap.

tes das que ocorrem para as eleições de 1989? Podemos desprezar a atuação dos partidos políticos neste pleito? O que ocorre nas eleições subsequentes fornece indicações sobre o que se passou nesses casos.

O pleito de $1994^{10}$, cuja novidade é o fato de que a eleição presidencial é "casada" com as demais, foi regulada pela Lei no 8.713/93, que determinou prazos diversos para a filiação partidária dos candidatos e para a distribuição do tempo de TV no horário eleitoral gratuito. Quanto ao primeiro ponto, o prazo estabelecido foi de 100 dias após a publicação da lei, aproximadamente dia 10/1/1994. O tempo no HGPE foi distribuído por cargo em disputa, guardando parte do tempo para a distribuição igual entre os partidos e parte para a distribuição proporcional entre os partidos com representação na Câmara dos Deputados conforme as bancadas partidárias na data da publicação da lei, que ocorreu em 1ㅇ de outubro de 1994.

A não concomitância das datas de distribuição do tempo do horário eleitoral e do fim do prazo de filiação partidária faz com que haja dois picos de migração (Gráfico 5), o primeiro entre setembro e outubro de 1993, e o segundo em janeiro de 1994. Fica claro, então, que tanto a restrição - prazo de filiação mínima - quanto o incentivo - distribuição do 
tempo do horário eleitoral - provocam movimentos migratórios intensos.

As eleições municipais de 1996 são regidas pela Lei no 9.100/95, que determinou que aqueles que quisessem ser candidatos deveriam estar filiados a um partido até 15 de dezembro de 1995.

Observamos, no Gráfico 6, que o número de trocas de legenda se acentua a partir de novembro de 1995, continua na trajetória ascendente em dezembro para, a partir da data de encerramento do prazo de filiação prévia e de contabilização do HGPE, diminuir de forma considerável.

Entre outubro de 1995 e 15 de dezembro do mesmo ano, ocorrem 43 trocas de legenda. A pergunta novamente é: por que os parlamentares trocam de legenda neste período? Trocam visando a eleição municipal de 1996? Ora, dos 43 parlamentares que trocam de legenda neste período, apenas 11 candidataram-se ao cargo de prefeito. Novamente aqui, a relação entre benefícios eleitorais para os parlamentares e trocas de legenda só pode ser feita de maneira indireta e, ainda assim, elaborando um cálculo complexo que envolve ganhos esperados que não serão contabilizados a não ser a longo prazo.

\section{Gráfico 6}

Número de Trocas de Legenda entre Fevereiro de 1995 e Fevereiro de 1996

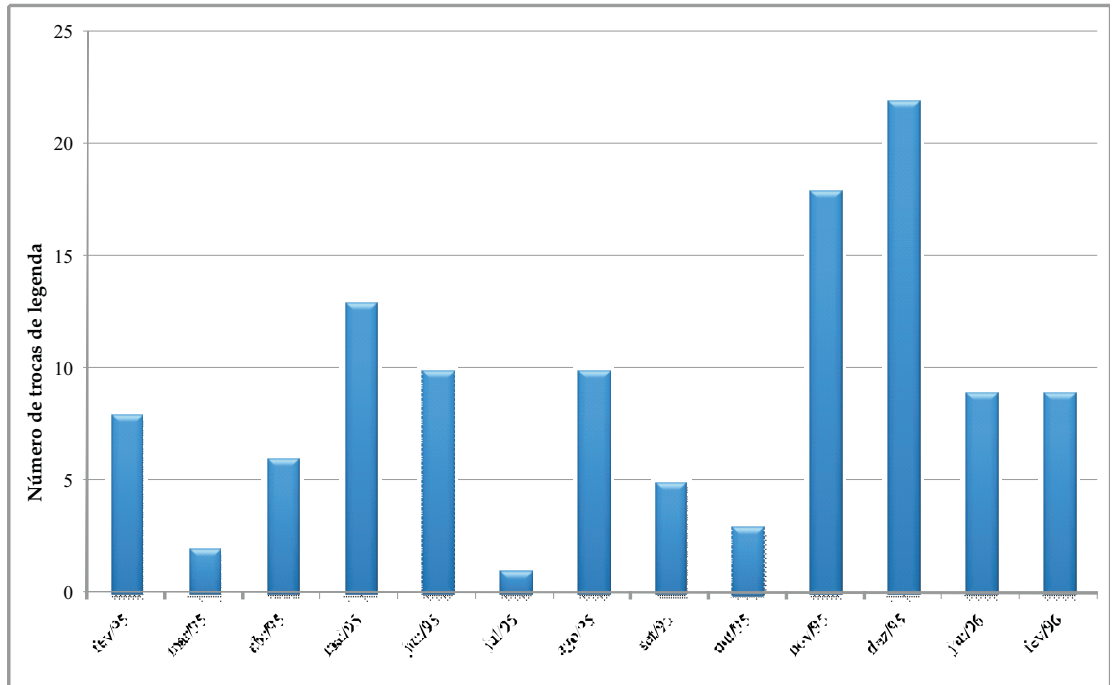

Fonte: Banco de Dados Legislativos, Cebrap. 
A eleição de 1998 foi regulada pela Lei no 9.504, de 30 de setembro de 1997. Como esta lei está em vigor até os dias de hoje, é interessante entender alguns aspectos de sua tramitação. O Projeto de Lei no 2.595/97, que origina esta lei, foi apresentado à Câmara em janeiro de 1997, mas só entrou em deliberação, de fato, em 8 de agosto de 1997. O PL no 2.595/97 determinava que os candidatos deveriam estar filiados aos partidos até sessenta dias após a publicação da lei. Determinava, ainda, que, para efeito de distribuição do tempo do horário eleitoral gratuito, as bancadas fossem contabilizadas em 15 de dezembro de 1997.

O relator da proposta, o deputado Carlos Apolinário (PMDB-SP), apresenta um substitutivo ${ }^{11}$ ao projeto original, modificando os dois artigos que tratam do tema, aumentando o prazo de filiação mínimo para um ano antes das eleições (dia 3/10/1997) e determinando que a distribuição do horário eleitoral gratuito seria proporcional às bancadas da Câmara dos Deputados no primeiro dia da legislatura. O relator argumenta que as modificações feitas na proposta original seriam necessárias para que a lei valesse não apenas para as eleições de 1998, mas para todas as eleições vindouras, oferecendo, assim, maior estabilidade ao sistema eleitoral. Nas palavras do relator: "Optamos [...] pela apresentação de um substitutivo que dê caráter mais duradouro à matéria, visando a disciplinar não apenas as eleições de 1998, mas também as seguintes" (DCD, 21/8/97:24.554).

No tocante ao tema deste trabalho, apenas um destaque foi votado, de autoria do deputado Valdemar Costa Neto (PL-SP), que solicitava que fosse mantido o artigo do projeto original referente ao tempo de filiação partidária, ou seja, que se desse aos deputados dois meses após a promulgação da lei para que pudessem trocar de legenda. A justificativa do autor da emenda é a seguinte: "[o destaque] há de interessar a cada deputado aqui presente, para que possa ter sessenta dias de prazo para definir a sua vida no seu estado" ( $D C D, 28 / 8 / 97: 5.432)$.

Na votação deste destaque, os líderes dos partidos, ao indicarem o voto para suas bancadas, justificam sua indicação. Essas justificativas, preciosas para o entendimento da questão das trocas de legenda no Brasil, foram apresentadas a seguir.

O líder do PPS, Sérgio Arouca (RJ), justificando seu voto "sim", argumenta (ibidem:25.432): 
Caminhamos no sentido da estabilização do quadro político, mas este é um momento de movimento. [...] acho absolutamente justo que se dê esse prazo de sessenta dias para as decisões [...]. [O destaque] dá a flexibilidade, que, de acordo com o movimento que esta casa está vivendo, é absolutamente necessária para que as pessoas encontrem seu nicho de identificação partidária.

O líder do PSB, Pedro Valadares (CE), afirma ao justificar seu voto "sim" (idem): "[...] a Lei Eleitoral vai ser publicada por volta de 3 de outubro e precisamos de tempo. [...]. Inclusive as pessoas não filiadas precisam de tempo para verificar qual o partido ao qual querem se filiar".

O deputado Fernando Gabeira (RJ), líder do PV, justifica sua indicação "sim" (idem): "[...] fico preocupado em ver a esquerda defender com tanto ardor a fidelidade partidária [...] quando se torna a fidelidade como fetiche, ela passa a ser um argumento basicamente conservador. [...] Acho que quem vê o seu partido se transformar em uma caricatura tem a obrigação de sair".

O líder do PPB, Gerson Peres (PA), por sua vez, justifica sua indicação "não": "[...] não queremos incentivar o poder de aliciamento de parlamentares [...], pois o povo julga o troca-troca como se estivéssemos atrás de vantagens" (ibidem:25.433, ênfase minha).

O líder do PMDB, Wagner Rossi (SP) justifica seu voto "não": "a fim de que evitemos aquilo que todos tememos, que é ver, daqui para frente, um agravamento severo desta política aliciadora" (idem).

Indicam voto contrário, ainda, os líderes partidários do PTB, PT, PSDB e PFL. A emenda foi rejeitada por votação simbólica.

A emenda do líder do PL encontrou apoio apenas entre alguns pequenos partidos e não obedeceu à cisão entre direita e esquerda, ou entre governo e oposição. Os termos usados pelos opositores da emenda são sugestivos: quer-se evitar o aliciamento. Esta observação não visa apontar a inconsistência dos partidos, contrários à política de aliciamento - e que, no entanto, a praticam -, mas corroborar a visão de que a explicação da migração partidária não pode se circunscrever às qualidades e características individuais do migrante.

A concentração das trocas de legenda em um dado período no tempo indica ainda que uma troca de partido pode estimular outras. Neste ponto, poderíamos imaginar que as trocas de legenda guardam seme- 
lhanças com o assurance game, ou jogo de convenções, em que embora as trocas de legenda possam causar um mal maior a longo prazo, só vale a pena não participar do jogo se ninguém participar, sob o risco de perder tanto no curto quanto no longo prazo. Ou seja, a maneira como se dão as relações sociais e as regras de conduta, formais e informais, são fundamentais para definir as opções disponíveis aos atores. Neste tipo de jogo, o agente tenderá a se comportar da mesma forma que o outro agente.

Temos, então, duas possibilidades de equilíbrio: se ninguém troca de partido, temos um ponto ótimo de Pareto ${ }^{12}$; no entanto, quando há uma troca de legenda, é melhor que os outros também troquem. A segunda opção também configura um equilíbrio, mas esta opção não será um ótimo social, pois os atores tenderam a tomar suas decisões conforme a expectativa que têm sobre o comportamento dos demais atores.

Outro ponto a ressaltar é que quando ocorrem trocas de legenda, alguns partidos políticos estão ganhando novos membros e outros estão perdendo, e poderíamos esperar que esse movimento gerasse nos partidos perdedores a necessidade de aliciarem novos membros, para não perder os benefícios distribuídos em função dos tamanhos das bancadas. Explorarei este tema mais adiante.

Derrotada a emenda de Valdemar da Costa Neto, o texto final da lei determinou filiação mínima de um ano para a disputa das eleições. Determinou, ainda, que o horário eleitoral fosse distribuído da seguinte forma: um terço, igualitariamente; dois terços, proporcionalmente ao número de representantes na Câmara dos Deputados, considerado, no caso de coligação, o resultado da soma do número de representantes de todos os partidos que a integram.

De acordo com a lei, a bancada a ser levada em conta nessa distribuição seria a da Câmara dos Deputados e a data para a contagem seria 1o de fevereiro do ano de início da legislatura.

Este ponto, a data de contabilização das bancadas para distribuição do HPGE, também foi objeto de debate. Novamente, aparece a necessidade de se evitar o aliciamento. José Genoíno (PT-SP) afirma ( $D C D$, 28/8/1997:25.448): "Lei Eleitoral não pode premiar a infidelidade [partidária]. O critério da divisão do tempo na televisão tem que ser o do número de deputados no momento em que assumiram o mandato, 
porque corresponde ao número de votos que receberam na eleição de 1994".

Novamente devemos ressaltar: a premiação a que o deputado José Genoíno se refere não é para o parlamentar individualmente, mas para o partido ao qual ele se filia. A questão é: impedir que os partidos aliciem novos filiados para, com isso, aumentar seu tempo de televisão.

No Gráfico 7, observamos o movimento migratório do período. Entre setembro e outubro se concentram, de forma mais acentuada, as migrações partidárias, ou seja, os movimentos ocorrem às vésperas do fim do prazo de filiação mínima para as eleições de 1998. Nesse período, ocorrem cerca de 50 trocas de legenda.

Observamos, ainda, que a partir de maio o número de trocas de legenda vem crescendo vagarosamente, e simplesmente se encerra em agosto, para voltar a crescer em setembro e outubro. Em agosto, como mencionado anteriormente, a lei começa a tramitar de maneira efetiva. É, portanto, um mês de grande incerteza para os parlamentares, que nesse momento não têm como calcular se será mantido o texto original da lei ou se será a provado o substitutivo do relator. Então, cessam as trocas de legenda até que se tenha uma definição, que vem por meio dos

\section{Gráfico 7}

Número de Trocas de Legenda entre Maio de 1997 e Dezembro de 1998

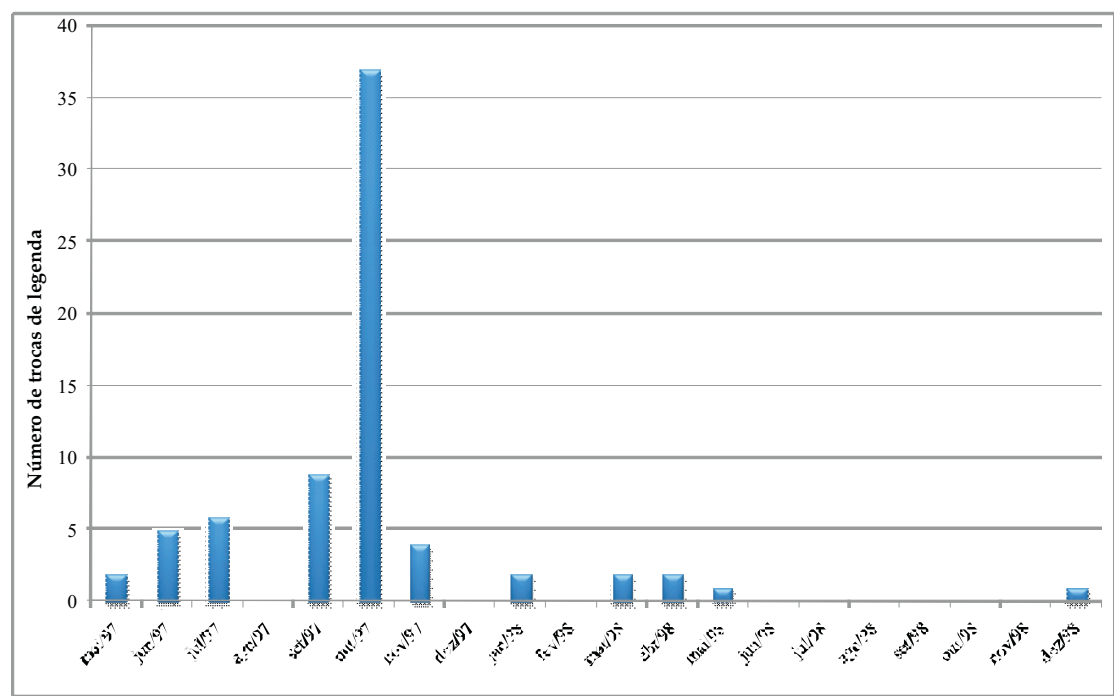

Fonte: Banco de Dados Legislativos, Cebrap. 
discursos dos líderes dos partidos na votação do destaque, que ocorreu em 28 de agosto de 1997. Assim, ficando evidente que o texto proposto pelo relator seria mantido, voltam as trocas de legenda. Mas o movimento se intensifica apenas no dia 30 de setembro, com a aprovação definitiva da matéria. Entre essa data e 3 de outubro, acontecem 37 das 50 mudanças de partido do período.

Como, para efeitos de distribuição do tempo no HGPE, a lei tomou como referência a bancada da Câmara no início da legislatura, esta distribuição não trouxe incentivos para a migração nesta eleição, mas, sim, limitação.

No entanto, e este ponto deve ser destacado, a Lei no 9.504/97 estabelece que, para efeito de distribuição do tempo do horário eleitoral gratuito, valem as bancadas partidárias que assumem em 1o de fevereiro de cada nova legislatura. A consequência desta mudança é que as trocas de legenda, a partir da legislatura de 2003, começam a ocorrer antes da posse. Até 2003, a Câmara não contabilizava as migrações que ocorriam antes da posse ${ }^{13}$, o que demonstra que elas não ocorriam, ocorriam pouco, ou simplesmente não eram consideradas importantes. A partir de 2003, a Câmara passa a contabilizar todas as trocas de legenda e suas datas antes mesmo da diplomação.

Mesmo que trocas de legenda ocorressem neste período e a Câmara apenas não as registrasse, ainda assim seria possível perceber a mudança que ocorre com a nova legislação, pois, antes da legislatura que se inicia em 1995, não acontece nenhuma troca de legenda no primeiro dia da legislatura. Em 1995, ocorrem 17 trocas de legenda no primeiro dia da legislatura. Já em 2003, ocorrem 47 mudanças entre a eleição e a posse. Em 2007, este número cai consideravelmente, mas, ainda assim, ocorrem 14 trocas de legenda entre a eleição e a posse.

Uma mudança considerável também ocorre nas trocas de legenda às vésperas do fim do prazo de filiação com vistas às eleições municipais. Como vimos, a migração partidária visando às eleições municipais de 1996 chegou à casa de 40 mudanças. Para a eleição municipal de 2000, às vésperas do prazo de filiação mínimo, ocorre apenas uma troca de legenda entre setembro e outubro, fim do prazo de filiação mínima com vistas às próximas eleições: a do deputado José Múcio Monteiro, que trocou de legenda e saiu candidato a prefeito. Em 2003, as trocas de legenda voltam a crescer, chegando a 23 neste período; dentre os parlamentares migrantes, apenas 16 concorrem a prefeituras em 2004. 
Ainda assim, deve-se destacar que as trocas de legenda com vistas à eleição subsequente não deixam de ocorrer, mas passam a se concentrar apenas nos meses de setembro e outubro do terceiro ano, quando ocorrem as eleições para deputados federais. Neste momento, os ganhos dos partidos políticos não são tão explícitos quanto nas datas de distribuição do HPGE, mas, ainda assim, não são desprezíveis.

Cada novo membro que entra em um partido traz consigo, no mínimo, os votos dos eleitores que permanecerem fiéis ao candidato. $\mathrm{O}$ sistema eleitoral brasileiro é proporcional de lista aberta e se utiliza do mecanismo de transferência de votos para determinar a distribuição das cadeiras entre os partidos. Isso faz com que cada voto seja importante. Dito de outra forma, cada parlamentar em posse de seu mandato, ainda que não repita a votação que obteve na eleição anterior, dificilmente não receberá votos, o que por si só já traz vantagens ao partido.

Vejamos, então: dos $603^{14}$ parlamentares que trocaram de partido entre 1995 e 2007, 265 foram para partidos ${ }^{15}$ que não haviam elegido sequer um parlamentar na eleição anterior no estado do deputado, o que equivale $44 \%$ dos migrantes. Isto a ponta para o fato de que os partidos políticos estão aliciando parlamentares em distritos onde foram mal na disputa eleitoral, para com isso expandirem seu eleitorado.

Mas isso significa que os parlamentares estão optando por partidos mais fracos? Na verdade, não. Lembremos que a correlação de forças entre os partidos no plano nacional é diferente da dos estados, assim mesmo os grandes partidos nacionalmente não elegem parlamentares em todos os estados. Na Tabela 3, podemos observar o número de trânsfugas que entraram em partidos que não haviam elegido nenhum parlamentar na eleição imediatamente anterior à troca de legenda, todos os sete maiores partidos do Brasil estão nesta lista.

No entanto, a constatação de que existem dois períodos nos quais as trocas de legenda se concentram, a saber, nos períodos pré-eleitorais e nos meses de fevereiro do primeiro e do terceiro ano das legislaturas. Falta, então, observar o que ocorre nos meses de fevereiro.

\section{Reflexos da Competição na Arena Parlamentar}

A movimentação nos meses de fevereiro do início das legislaturas é explicada em parte pela última legislação eleitoral, que determinou que a distribuição do horário eleitoral gratuito deve ser proporcional às ban- 


\section{Tabela 3}

Número de Parlamentares que Migraram para Partidos que não Elegeram Parlamentares na Eleição Imediatamente Anterior à Troca de Legenda nas Legislaturas de 1995, 1999, e de 2003, 2007

\begin{tabular}{|c|c|}
\hline Partido na Eleição2 & Migrantes \\
\hline $\mathrm{PDS}>\mathrm{PP}$ & 74 \\
\hline $\mathrm{PL}>\mathrm{PR}$ & 35 \\
\hline РТВ & 22 \\
\hline PCB $>$ PPS & 17 \\
\hline PFL $>$ DEM & 16 \\
\hline PSB & 15 \\
\hline PSDB & 15 \\
\hline PDT & 13 \\
\hline PSC & 10 \\
\hline PMDB & 9 \\
\hline PSOL & 7 \\
\hline PCdoB & 6 \\
\hline PSL & 4 \\
\hline PST & 4 \\
\hline $\mathrm{PRB}>\mathrm{PMR}$ & 3 \\
\hline PV & 2 \\
\hline PT & 2 \\
\hline PTN & 2 \\
\hline PHS & 1 \\
\hline PFL & 1 \\
\hline $\mathrm{PJ}>\mathrm{PTC}$ & 1 \\
\hline PL & 1 \\
\hline PPS & 1 \\
\hline PRTB & 1 \\
\hline PSD & 1 \\
\hline PSTU & 1 \\
\hline PRONA & 1 \\
\hline Total & 265 \\
\hline
\end{tabular}

Fonte: Banco de dados legislativos do Cebrap.

cadas dos partidos no primeiro dia das legislaturas, ou seja, dia 1o de fevereiro. Mas, é fato que as trocas de legenda se arrastam pelo mês de fevereiro, para além do primeiro dia da legislatura, o que pede uma ex- 
plicação. Também há a necessidade de explicarmos as trocas de legenda que ocorrem em fevereiro do terceiro ano da legislatura. Este é o objetivo desta seção.

Assim como a legislação eleitoral, o Regimento Interno da Câmara dos Deputados também produz incentivos para a migração partidária. No parlamento brasileiro, assim como em outros parlamentos do mundo, tamanho importa. Os recursos, nas Casas legislativas, são distribuídos proporcionalmente ao tamanho das bancadas dos partidos políticos. Na tramitação das matérias há a interposição de requerimentos e procedimentos em que a assinatura dos líderes partidários, por exemplo, é ponderada pelo número de parlamentares que compõem suas bancadas $^{16}$. Temos então, que quanto maior o partido, mais acesso ele tem aos recursos que de fato influenciam nas decisões sobre políticas.

Dentre as regras estabelecidas pelo Regimento Interno da Câmara dos Deputados, a que determina a distribuição de cargos na Mesa Diretora e nas comissões parlamentares parece ser a que mais diretamente influencia a ocorrência de trocas de legenda. Essa distribuição é regulada por dois artigos, a saber: o art. 8, que determina que, sempre que possível, a composição da Mesa Diretora da Casa deve respeitar a proporcionalidade dos partidos políticos; e o art. 25, que determina que os cargos nas comissões são distribuídos, também, por critérios de proporcionalidade. Estes cargos, até recente alteração do regimento, em 2005, eram distribuídos pelos partidos segundo a bancada do início de fevereiro, em uma data definida ad hoc pelo presidente da mesa, do primeiro ano e do terceiro ano legislativo.

Ainda há uma regra informal na Câmara dos Deputados para a distribuição das presidências das comissões, que também é feita segundo o tamanho das bancadas na Câmara dos Deputados. Ou seja, o maior partido da Câmara escolhe primeiro a comissão a qual ele presidiria, seguido pelo segundo maior partido, até que todas as comissões tenham presidentes.

Em 2005, é aprovada a Resolução no 34, que modifica de forma significativa esta regra. As novas regras aprovadas neste ano passaram a vigorar na legislatura de 2007. A nova redação dada ao artigo que trata da composição da mesa é: 
Art. 8 - Na composição da Mesa será assegurada, tanto quanto possível, a representação proporcional dos Partidos ou Blocos Parlamentares [...]

$\S 4$ 을 As vagas de cada Partido ou Bloco Parlamentar na composição da Mesa serão definidas com base no número de candidatos eleitos pela respectiva agremiação, na conformidade do resultado final das eleições proclamado pela Justiça Eleitoral, desconsideradas as mudanças de filiação partidária posteriores a esse ato.

§5o Em caso de mudança de legenda partidária, o membro da Mesa perderá automaticamente o cargo que ocupa, aplicando-se para o preenchimento da vaga o disposto no $\S 2$ o deste artigo (Regimento Interno da Câmara dos Deputados, ênfase minha).

Sobre a distribuição dos cargos nas Comissões, o texto do regimento institui:

Art. 26 A distribuição das vagas nas Comissões Permanentes entre os Partidos e Blocos Parlamentares será organizada pela Mesa logo após a fixação da respectiva composição numérica e mantida durante toda a legislatura. [...]

$\S 4$ o As alterações numéricas que venham a ocorrer nas bancadas dos Partidos ou dos Blocos partidários decorrentes de mudança de filiação partidária não importarão em modificação na composição das Comissões, cujo número de vagas de cada representação partidária será fixada pelo resultado final obtido nas eleições e permanecerá inalterado durante toda a legislatura (Regimento Interno da Câmara dos Deputados).

As alterações regimentais determinam ainda que os deputados que mudarem de partido perderão os cargos ou funções que ocuparem em razão do partido. O deputado Bismarck Maia (PSDB-CE), autor do Projeto de Resolução no 239/05, ao justificar o projeto afirma que:

Com esta medida, estaremos mostrando à sociedade que as mudanças de legendas por parte de Parlamentares seriam efetuadas por razões diversas, como, por exemplo, afinidade programática com determinada legenda, possibilidade de ser candidato a outro cargo eletivo ou mesmo o de Deputado, por outro partido com melhores coligações e mais chances de vitória, mas, em nenhum momento, uma nova filiação com suposições de troca de cargos e vendas de voto que mancham negativamente todos nós desta Casa perante a sociedade ( $D C D$, 8/3/1995:4.780). 
A votação da resolução foi tranquila, marcada por discursos elogiosos e pela afirmação constante de que as novas regras representavam a "observância da vontade popular expressa nas urnas" (idem). O projeto foi objeto de acordo entre os líderes e, portanto, aprovado por unanimidade.

No Gráfico 8, podemos observar as trocas de legenda ocorridas entre fevereiro e agosto nas legislaturas 1995, 1999, 2003, 2007. Verifica-se que as mudanças de partido ocorridas em fevereiro de 2007 são bastante inferiores se comparadas às legislaturas anteriores, exceção feita à legislatura iniciada em 1995. Em fevereiro de 2007, ocorrem apenas 17 trocas de legenda. Em 1999, só no mês de fevereiro foram realizadas 93 trocas de legenda e, em 2003, são realizadas 55 mudanças de partido.

Obviamente, não podemos descartar o efeito que a Resolução n№22.526 do Tribunal Superior Eleitoral teve sobre as mudanças de partido. Ao responder à consulta feita pelo então PFL, o TSE colocou em risco o mandato dos migrantes, ao entender que o mandato pertence ao partido e não ao candidato. A incerteza gerada pela decisão do TSE possi-

Gráfico 8

Número de Trocas de Legendas Ocorridas entre Fevereiro e Agosto das Legislaturas de 1995, 1999, e de 2003, 2007

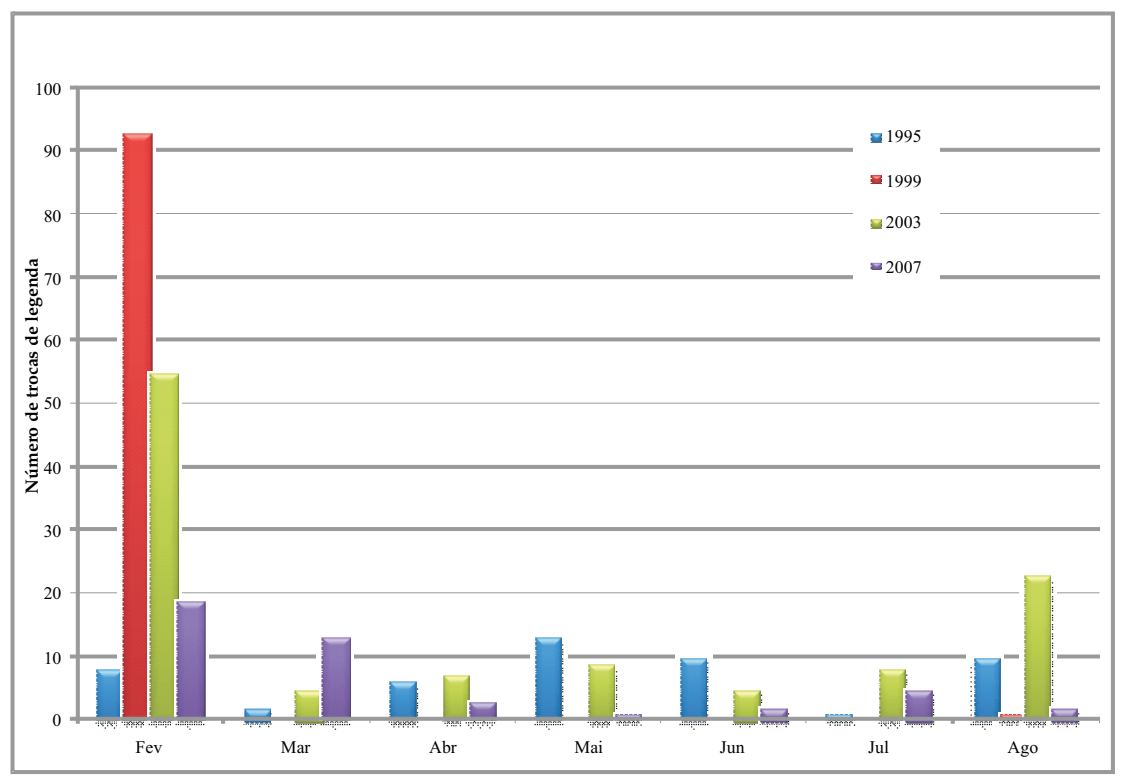

Fonte: Banco de dados legislativos do Cebrap. 
velmente inibiu a migração. Mas o fato de a Resolução ter sido publicada em 27 de março de 2007 possibilita que comparemos, pelo menos, o primeiro mês das legislaturas. Ou seja, ainda que a decisão do TSE tenha reduzido as trocas de legenda, no mês de fevereiro ainda não era possível prever que o Tribunal decidiria em favor dos partidos. Até porque, em 1989, o mesmo TSE já havia sido consultado sobre a questão e, na época, decidiu por unanimidade, que não havia bases na legislação eleitoral e partidária para que se concluísse que o mandato pertencia ao partido e não ao parlamentar.

Como já mencionado, as trocas de legenda que ocorrem em fevereiro são explicadas pela distribuição no horário eleitoral gratuito e pela distribuição dos cargos em comissões. Em 2007, das 17 trocas que ocorrem em fevereiro, 14 ocorreram até 1 으 de fevereiro, ou seja, até a data em que é distribuído o HGPE. Assim só ocorreram trocas em fevereiro no momento em que interessava aos partidos aumentar seu tempo no horário eleitoral gratuito.

A redução significativa do número de trocas de legenda em fevereiro de 2007 é explicada pela modificação no Regimento Interno da Câmara dos Deputados. Como afirmei anteriormente, os recursos na Câmara dos Deputados são escassos. Cada entrada de um novo membro no partido implica, ao menos em teoria, uma diminuição dos recursos para os demais membros do partido. Se a entrada de um novo membro não acrescenta recursos ao partido, este não tem por que aceitar ou procurar novos membros.

\section{CONCLUSÃO}

Como foi visto a distribuição de recursos caros aos partidos políticos, afeta diretamente o movimento dos parlamentares entre as legendas,

Tabela 4

Concentração das Trocas de Legenda nas Legislaturas 1995, 1999, 2003 e 2007*

\begin{tabular}{l|c|c}
\hline Períodos & No de Trocas de Legenda & Porcentagem de Trocas de Legenda \\
\hline Pré-Comissões & 307 & 34,4 \\
Pré-Eleitoral & 291 & 32,6 \\
Subtotal & 598 & 67,0 \\
Outros Períodos & 295 & 33,0 \\
\hline Total & $\mathbf{8 9 3}$ & $\mathbf{1 0 0 , 0}$ \\
\hline
\end{tabular}

Fonte: Banco de Dados Legislativos, Cebrap.

*Última atualização: 25/10/2009. 
mudando o período de sua concentração e mesmo reduzindo quando cessam os incentivos. Estes recursos são distribuídos aos partidos diretamente e os parlamentares só tem acesso a eles por meio dos partidos.

Entre 1995 e 2007, cerca de 70\%, das trocas de legenda ocorrem nos períodos pré-eleitorais e nos períodos pré-distribuição dos cargos em comissão. Os dois períodos, como vimos, são de extrema importância para os partidos políticos, pois é quando se define a distribuição de recursos que serão decisivos para a configuração de forças na disputa eleitoral e na Câmara dos Deputados. Para a disputa eleitoral com as trocas de legenda, os partidos ganham tempo no HPGE, e também ganham votos em regiões onde não tinham sido bem votados.

O fato de uma porcentagem significativa das trocas de legenda se dar para partidos que não haviam eleito deputados no estado de origem do migrante é um indício de que a migração partidária faz parte da estratégia dos partidos políticos para expandirem seu eleitorado.

$\mathrm{Na}$ arena parlamentar existia uma forte associação entre a distribuição dos cargos no legislativo e as trocas de legenda. Vimos que ao diminuir os incentivos aos partidos, se reduz, de forma significativa, o número de trocas de legenda.

Assim, ainda que não dê conta da explicação da totalidade do fenômeno, uma vez que o artigo aborda apenas o ponto de vista dos partidos, a mudança no foco da análise possibilita que afinemos nosso entendimento do papel dos partidos políticos a cada troca de legenda. Como foi possível observar, diferentemente do que imaginamos, as trocas de legenda não são reflexo da fragilidade dos partidos políticos brasileiros, mas uma forma diferente que estes encontraram para se organizar.

(Recebido para publicação em novembro de 2011)

(Reapresentado em fevereiro de 2012) (Aprovado para publicação em maio de 2012) 


\section{NOTAS}

1. Melo é o primeiro a apontar que os partidos políticos têm uma participação nas trocas de legenda, nas palavras do autor: "[são] os próprios líderes que se encarregam de patrocinar as migrações" (2004:171). Desposato, afirma que os partidos políticos podem "convidar, rejeitar, ou expulsar membros para maximizar a utilidade da maioria dos seus filiados" (2005:63, tradução da autora). No entanto, em suas análises, eles optam por explorar as trocas de legenda a partir da ótica do migrante.

2. Foi considerada uma troca de legenda a saída de um parlamentar de um determinado partido, mesmo quando ele não entra em outro e permanece sem partido. Não foram considerados migrantes os parlamentares que estavam em partidos que se fundiram, tampouco os parlamentares que estavam em partido que mudaram de nome.

3. A constatação de que as trocas de legenda se concentram no tempo não é nova, foi apontada por Araújo (2000), e, depois, por Melo (2004), que melhor explora hipóteses em torno desta questão, ao afirmar que os parlamentares trocam de legenda em momentos decisivos para suas carreiras. Diniz (2000) também trata especificamente da relação entre migração partidária e a distribuição do HGPE.

4. Os partidos classificados como satélites são aqueles que votam com a coalizão governista de forma sistemática, ainda que não façam parte da base formal do governo, ou seja, ainda que não possuam pastas ministeriais. Para classificá-los, calculei a disciplina média dos parlamentares de cada um dos partidos em relação ao governo, comparando o voto dos parlamentares com a indicação do líder do governo. Desconsiderei no cálculo as votações invalidadas, unânimes, as votações em que o líder do partido do presidente e o líder do maior partido da oposição indicam o mesmo voto e, por fim, as votações em que o líder do governo não indica voto. O objetivo é captar apenas as votações conflituosas, de modo a tornar mais acentuada a disciplina destes partidos em relação ao governo. Sendo assim, foram considerados satélites aqueles partidos que votam com o líder do governo em índice superior ao menor apoio registrado entre os partidos que fazem parte formalmente da coalizão governistas. O que significa $85 \%$ de disciplina em relação ao governo.

5. Pode-se argumentar que classificar estes partidos a partir da forma como eles votam em plenário, causa viés, pois seria uma classificação ex-post, no entanto, existem diferenças significativas nos recursos a que estes partidos acessam. Apenas para exemplificar as taxas de execução orçamentária dos filiados a esses partidos são muito semelhantes às taxas de execução dos parlamentares da coalizão, como observado por Freitas e Mesquita (2008), o que por si só já justifica a separação dos satélites da oposição, uma vez que estes partidos têm acesso diferenciado a recursos do Executivo.

6. Para a tabela com as legislaturas desagregadas ver Apêndice, para maiores explicações de como ela foi montada ver Freitas (2009).

7. Foram considerados períodos pré-eleitorais os três meses anteriores à data de filiação mínima definida para a eleição. Esta data variou até a legislação aprovada em 1998, que passou a determinar que o tempo de filiação mínimo é um ano antes da eleição. Mas veremos em detalhes as datas definidas em cada uma das eleições a seguir.

8. Em Diniz (2000), podemos ver de forma detalhada o debate travado entre os líderes partidários na Câmara dos Deputados em torno do tema. 


\section{Andréa Freitas}

9. O PMDB e PFL foram excluídos do gráfico para torná-lo mais claro, posto que o grande número de deputados que estes possuíam (105 e 199, na data inicial do gráfico) acabava por impossibilitar a visão dos demais partidos. Para constar, a linha dos dois partidos é levemente descendente até a data limite, quando sofre uma queda acentuada.

10. As eleições municipais de 1992 são reguladas pela Lei no 8.214 /91, que estabelece as normas para a realização da eleição e entre outras coisas, determina a distribuição do HGPE. No entanto, a distribuição do tempo no HGPE é feita segundo a representação dos partidos na Câmara dos Deputados, Senado Federal e Assembleias Legislativas. Não há um pico elevado de trocas de legenda neste período, que pode ter acontecido nas Assembleias Legislativas e não na Câmara dos Deputados. Em função da falta de informação sobre a composição das Assembleias não analisarei este período.

11. O substitutivo apresentado pelo relator previa, ainda, financiamento público de campanha e coligações apenas para as eleições majoritárias, temas polêmicos dentro do Congresso Nacional. Foram apresentadas mais de uma centena de emendas a proposta do relator e grande parte delas foram votadas em plenário.

12. Uma situação econômica é ótima, no sentido de Pareto, se não for possível melhorar a situação, ou, mais genericamente, a utilidade de um agente sem degradar a situação ou utilidade de qualquer outro agente econômico.

13. A Câmara contabilizava os partidos da eleição e os partidos da posse e inseria todas as diferenças em $1 \stackrel{0}{-}$ de fevereiro, data da posse. Não tenho como precisar se estas mudanças ocorreram antes da legislatura ou no primeiro dia da legislatura. Independente disso, o argumento não é invalidado.

14. Considerei apenas os migrantes que trocaram de legenda entre a legislatura de $1995 \mathrm{e}$ de 2007, incluído as trocas que ocorreram em outubro de 2009, pois disponho apenas dos dados das eleições 1995, 1998, 2002, 2003 e 2006. A fonte dos dados eleitorais é o banco de dados eleitorais CEM/Cebrap.

15. Para esta avaliação foi considerado o partido de destino, o último partido para qual o parlamentar mudou. Ou seja, o partido no qual ele concorreu na eleição seguinte.

16. O pedido de urgência urgentíssima e mesmo o acesso à palavra também são concedidos segundo este critério. 


\section{REFERÊNCIAS BIBLIOGRÁFICAS}

ARAÚJO, Marcelo. (2000), Mudança Partidária - 1979-1999. Dissertação de Mestrado. São Paulo, FFLCH/Universidade de São Paulo.

DESPOSATO, Scott. (2006), “Parties for Rent? Ambition, Ideology, and Party-Switching in Brazil's Chamber of Deputies". American Journal of Political Science, vol. 50, no 1, pp. 62-80.

DINIZ, Simone. (2000), "As Migrações Partidárias e o Calendário Eleitoral". Revista de Sociologia e Política, no 15, pp. 31-48.

FIGUEIREDO, Argelina Cheibub. (2007), "Government Coalitions in Brazil Democracy". Brazilian Political Science Review, vol. 3, no 2, pp. 182-216.

e LIMONGI, Fernando. (1999), Executivo e Legislativo na Nova Ordem Constitucional. Rio de Janeiro, FGV Editora.

FREITAS, Andréa. (2008), "Infidelidade Partidária e Representação Política: Alguns Argumentos sobre a Migração Partidária no Brasil”. Caderno CRH, vol. 21, no 52, pp. $37-45$.

. (2009), Migração Partidária na Câmara dos Deputados. Dissertação de Mestrado em Ciência Política. São Paulo, FFLCH/Universidade de São Paulo.

LAMOUNIER, Bolívar. (1994), “A Democracia Brasileira de 1985 à Década de 1990: A Síndrome da Paralisia Hiperativa", in J. P. dos R. Velloso (org.), Governabilidade, Sistema Político e Violência Urbana. Rio de Janeiro, José Olympio, pp. 25-63.

e MENEGUELLO, Rachel. (1986), Partidos Políticos e Consolidação Democrática: O Caso Brasileiro. São Paulo, Brasiliense.

LIMA JUNIOR, Olavo Brasil de. (1993), “A Representação Política e a Composição Partidária do Legislativo", in O. B. de Lima Junior (org.), Democracia e Instituições Políticas no Brasil dos Anos 80. São Paulo, Loyola, pp. 65-89.

MAINWARING, Scott. (1991), "Políticos, Partidos e Sistemas Eleitorais". Novos Estudos CEBRAP, no 29, pp. 34-58.

MELO, Carlos Ranulfo de. (2004), Retirando as Cadeiras do Lugar, Migração Partidária na Câmara dos Deputados (1985-2002). Belo Horizonte, Editora UFMG.

MERSHON, Carol; HELLER, William. (2003), Party Switching and Political Careers in Spanish Congress of Deputies, 1982-1996. Trabalho apresentado no Encontro Anual da Midwest Political Science Association, Palmer House Hilton, Chicago, 3-6 de abril.

(2004), Theoretical and Empirical Models of Party Switching. Trabalho apresentado no Dublin Meeting of the Research, Work Group on Legislative Party Swtching.

. (2005), Legislator Preferences, Party Desires: Party Switching and the Foundations of Policy Making in Legislatures. Trabalho apresentado no Encontro Anual da International Studies Association, Honolulu, 1-5 de março.

NICOLAU, Jairo Marconi. (1996), Multipartidarismo e Democracia. Rio de Janeiro, FGV Editora. 


\section{Andréa Freitas}

SANTOS, André Marenco. (2001), “Sedimentação de Lealdades Partidárias no Brasil: Tendências e Descompassos". Revista Brasileira de Ciências Sociais, no 45, pp. 69-83.

TSEBELIS, George. (1998), Jogos Ocultos. São Paulo, Edusp. 


\section{APÊNDICE}

Trocas de Legenda

Origem e Destino a partir da Posição do Partido em relação ao Governo

\begin{tabular}{|c|c|c|c|c|c|c|}
\hline Legislatura & $\begin{array}{l}\text { Destino } \\
\text { Origem }\end{array}$ & Coalizão & Satélite & Oposição & $\begin{array}{c}\text { Sem } \\
\text { Partido }\end{array}$ & Total \\
\hline \multirow{5}{*}{1987} & Coalizão & 2,7 & 0,0 & 61,0 & 1,2 & 65,0 \\
\hline & Satélite & 0,0 & 0,6 & 0,0 & 0,0 & 0,6 \\
\hline & Oposição & 10,6 & 0,0 & 21,5 & 1,5 & 33,5 \\
\hline & Sem Partido & 0,6 & 0,0 & 0,3 & 0,0 & 0,9 \\
\hline & Subtotal & 13,9 & 0,6 & 82,8 & 2,7 & 100,0 \\
\hline \multirow{5}{*}{1991} & Coalizão & 9,0 & 14,7 & 10,2 & 1,1 & 35,0 \\
\hline & Satélite & 6,8 & 9,0 & 4,9 & 0,4 & 21,1 \\
\hline & Oposição & 9,8 & 11,3 & 19,9 & 1,1 & 42,1 \\
\hline & Sem Partido & 0,8 & 0,0 & 1,1 & 0,0 & 1,9 \\
\hline & Subtotal & 26,3 & 35,0 & 36,1 & 2,6 & 100,0 \\
\hline \multirow{5}{*}{1995} & Coalizão & 25,1 & 16,9 & 3,7 & 0,5 & 46,1 \\
\hline & Satélite & 28,3 & 4,1 & 1,8 & 1,4 & 35,6 \\
\hline & Oposição & 8,2 & 2,7 & 2,7 & 2,3 & 16,0 \\
\hline & Sem Partido & 2,3 & 0,0 & 0,0 & 0,0 & 2,3 \\
\hline & Subtotal & 63,9 & 23,7 & 8,2 & 4,1 & 100,0 \\
\hline \multirow{5}{*}{1999} & Coalizão & 31,6 & 0,4 & 28,3 & 0,8 & 61,2 \\
\hline & Satélite & 0,8 & 0,0 & 0,4 & 0,0 & 1,3 \\
\hline & Oposição & 17,3 & 0,0 & 19,4 & 0,4 & 37,1 \\
\hline & Sem Partido & 0,4 & 0,0 & 0,0 & 0,0 & 0,4 \\
\hline & Subtotal & 50,2 & 0,4 & 48,1 & 1,3 & 100,0 \\
\hline \multirow{5}{*}{2003} & Coalizão & 21,0 & 12,0 & 11,7 & 1,7 & 46,3 \\
\hline & Satélite & 9,3 & 2,7 & 3,7 & 0,7 & 16,3 \\
\hline & Oposição & 23,0 & 4,3 & 6,7 & 2,0 & 36,0 \\
\hline & Sem Partido & 0,7 & 0,0 & 0,7 & 0,0 & 1,3 \\
\hline & Subtotal & 54,0 & 19,0 & 22,7 & 4,3 & 100,0 \\
\hline \multirow{6}{*}{2007} & Coalizão & 19,3 & 18,1 & 2,4 & 3,6 & 43,4 \\
\hline & Satélite & 2,4 & 2,4 & 0,0 & 0,0 & 4,8 \\
\hline & Oposição & 34,9 & 2,4 & 3,6 & 3,6 & 44,6 \\
\hline & Sem Partido & 3,6 & 2,4 & 1,2 & 0,0 & 7,2 \\
\hline & Subtotal & 60,2 & 25,3 & 7,2 & 7,2 & 100,0 \\
\hline & Total & 40,9 & 15,7 & 40,1 & 3,3 & 100,0 \\
\hline
\end{tabular}

Fonte: Banco de Dados Legislativos, Cebrap. 


\section{ABSTRACT \\ Switching Party Affiliations in the Brazilian Chamber of Deputies from 1987 to 2009}

This study analyzes the phenomenon of switching party affiliations in Brazil, taking a different approach from that traditionally adopted. Rather than inquiring into the intentions of the migrating legislators, I attempt to understand party-switching as a whole, seeking to grasp how the collective actors (in this case the political parties) use party switches to increase their power in the parliamentary and electoral arenas. By focusing on the moments in which party switches occur, it is possible to perceive the benefits derived by political parties whenever new members join their ranks.

Key words: Political Parties; partisan migration; political institutions, Parliamentary Arena, Electoral Arena

\section{RÉSUMÉ}

Les Migrations entre Partis à la Chambre des Députés entre 1987 et 2009

Ce travail s'efforce d'analyser sous un jour inédit le phénomène du changement de parti au Brésil. Au lieu de me concentrer sur les ambitions de celui qui migre, $j$ 'ai essayé de comprendre les changements de parti dans leur ensemble, d'appréhender la façon dont les acteurs collectifs, en l'occurrence les partis politiques, utilisent ces migrations afin d'augmenter leur pouvoir au sein de l'arène parlementaire et de l'arène électorale. Comme nous le verrons en examinant ce qui se produit lors des périodes où les changements de partis se concentrent, il est possible de percevoir les bénéfices que les partis politiques obtiennent à chaque fois qu'un nouveau membre vient intégrer leurs rangs.

Mots-clés: Partis politiques, Migration entre partis, Institutions Politiques, Arène Parlementaire, Arène Électorale. 